\title{
Increased ammoniagenesis and the renal tubular effects of potassium depletion
}

\author{
DStJ O'REILLY \\ From the Department of Pathological Biochemistry, Royal Infirmary, Glasgow, G4 OSF
}

SUMMARY The cause of the morphological changes and functional defects in the renal tubule seen in patients with severe potassium depletion is unknown. In man and animals potassium status is a major factor regulating ammonia synthesis in the kidney and urinary ammonium excretion. A primary effect of potassium depletion is to cause an increase in ammoniagenesis by the renal tubular cells. It is proposed that the vacuolation of the renal tubular cells and the functional defects of tubular proteinuria, polyuria, resistance to arginine vasopressin, renal resistance to the action of parathyroid hormone, and increased urinary excretion of $\mathrm{N}$-acetyl- $\beta$-glucosaminidase found in potassium depletion are secondary effects caused by high concentrations of ammonia in the renal tubular cells.

It has been recognised since 1937 that potassium depletion is associated with vacuolation of the renal tubular cells.' It was subsequently shown in 1956 by Relman and Schwartz ${ }^{2}$ that this vacuolation, most prominent in the proximal convoluted tubule, is reversed in man by potassium repletion. More recently, experimental studies in the rat kidney have shown that this is lysosomal vacuolation. ${ }^{3}$ This vacuolation is associated with defects in tubular function which have received a lot of attention. Polyuria and a reversible resistance to the antidiuretic hormone arginine vasopressin have been noted in man. ${ }^{2}$ In the rat kidney cyclic AMP production in response to arginine vasopressin and parathyroid hormone is also impaired. ${ }^{45}$ In man there is reversible tubular proteinuria, ${ }^{6}$ and more recently an increase in the urinary excretion of the lysosomal enzyme $\mathrm{N}$-acetyl- $\beta$-glucosaminidase, (E.C.3.2.1.52 NAG) has been found.?

Renal glycosuria has been described as a late feature in two patients with potassium depletion secondary to chronic nephritis associated with increased urinary potassium loss. ${ }^{89}$ Both patients were complex, and potassium depletion was secondary to, rather than the cause of, their renal disease. Apart from these patients, renal glycosuria has not been commented on in potassium depletion. Renal glycosuria does not seem to occur in potassium depleted animals. ${ }^{10}$ Aminoaciduria is not usually a feature of potassium depletion. It was present in one

Accepted for publication 14 August 1984 of the patients referred to above with glycosuria, ${ }^{8}$ and aminoaciduria has also been reported during the postoperative period in two patients with potassium depletion. ${ }^{11}$ In these patients other causes of aminoaciduria cannot be excluded. When specifically looked for in patients with potassium depletion due to primary hyperaldosteronism aminoaciduria was not present. ${ }^{12}$ The evidence that potassium depletion causes renal glycosuria and aminoaciduria is tenuous.

\section{Potassium depletion and renal ammoniagenesis}

Patients who are potassium depleted (as a result of excessive gastrointestinal ${ }^{13}$ or renal ${ }^{14}$ potassium losses) show increased urinary ammonia excretion. This also occurs in experimentally induced potassium depletion. ${ }^{1516}$ Conversely, the administration of potassium supplements decreases urinary ammonia excretion. ${ }^{17}$ This indicates that there is an inverse relation between potassium status and urinary ammonia excretion. That this is related to the rate of ammonia production in the renal tubular cells is shown by increased ammoniagenesis in tissue slices $^{18}$ and isolated mitochondria ${ }^{19}$ prepared from the kidneys of potassium depleted animals.

Glutamine is the major substrate for renal ammoniagenesis and the mitochondria are the major site of ammonia production. ${ }^{20}$ At a molecular level potassium depletion stimulates the entry of glutamine into mitochondria ${ }^{21}$ and causes an increase in the activity of both phosphate dependent 
glutaminase (L-glutamine amidohydrolase, E.C.3.5.1.2.) and glutamate dyhydrogenase (Lglutamate: $\mathrm{NAD}^{+}$oxidoreductase, E.C.1.4.1.2.), thus increasing mitochondrial ammoniagenesis. ${ }^{19}$ Potassium depletion also stimulates cytosolic ammoniagenesis from glutamine by increasing the activity of glutamine transaminase [L-glutamine 2-oxo-acid aminotransferase, E.C.2.6.1.15]. ${ }^{22}$ Ammonia production from aspartate is also increased as a result of increased synthesis and activity of adenylosuccinate synthetase (IMP: L-aspartate ligase, E.C.6.3.4.4.) and adenylosuccinase (adenylosuccinate AMP-lyase, E.C.4.3.2.2.), thus stimulating the purine nucleotide cycle. ${ }^{23}$ The synthesis of glutamine from glutamate is inhibited in potassium depletion, thus decreasing ammonia consumption by the cell. ${ }^{24}$ Conversely, an increased potassium concentration inhibits ammoniagenesis in vitro in rat and canine renal tissue slices. ${ }^{25}$ Clearly, potassium depletion increases ammonia production by the kidney.

The effects of increased ammoniagenesis on renal tubular function have received some attention. It is of considerable importance for potassium homeostasis that the increase in urinary ammonia excretion, resulting from increased renal ammoniagenesis, is directly associated with a decrease in urinary potassium excretion. ${ }^{26}$ The effect of increased ammoniagenesis enables an increase in acid excretion by the kidney in the absence of a low urinary $\mathrm{pH}^{27}$ Other investigators maintain, however, that in addition to stimulating ammoniagenesis potassium depletion impairs the ability of the distal nephron to generate and maintain a $\mathrm{pH}$ gradient across the tubular cells. ${ }^{28}$ Other effects of ammonia and ammonium on cell morphology and function have recently been the subject of much research. This work, which for technical reasons has to be performed on cells in tissue culture, is relevant to many of the effects of potassium depletion on renal tubular cell morphology and function.

\section{Ammonia, ammonium, and cell function}

In the biological published work the terms ammonia and ammonium are often used synonymously. This is especially true when reference is being made to the measurement of ammonia or ammonium in biological fluids. The methods used to measure blood or plasma ammonia in fact measure total ammonium plus ammonia, but the result is referred to as being a blood or plasma ammonia level. ${ }^{29-34}$ This loose use of terminology suggests that the biological properties of ammonia and ammonium are similar, if not identical, which is not so.

Ammonia $\left(\mathrm{NH}_{3}\right)$ is lipophilic and diffuses rapidly throughout cells and through biological membranes. Ammonium $\left(\mathrm{NH}_{4}^{+}\right)$is hydrophilic and does not cross biological membranes, except in some bacteria, fungi, plants, and ammoniotelic aquatic animals which have an ammonium transport mechanism. ${ }^{35}$ The dissociation constant for $\mathrm{NH}_{4}{ }^{+}$is $1.26 \times$ $10^{-9}(\mathrm{pk}=8.90)$ in aqueous solutions at $37^{\circ} \mathrm{C}$, so that in biological systems the concentration of the ammonium is far greater than that of ammonia. ${ }^{36}$

Vacuolation of nucleated cells by ammonia was shown by Heinz in $1890^{37}$ and this has subsequently been shown to be due to lysosomal swelling and vacuolation. ${ }^{38}$ The mechanism for this is that in the lysosome ammonia is protonated to the ammonium ion, and as a result it is trapped within the acid lysosomes where it exerts an osmotic effect leading to swelling and vacuolation (Fig. 1). Amines with this property of ammonia/ammonium are called lysosomotropic amines. ${ }^{39}$ Cells in tissue culture become vacuolated with concentrations of ammonium in the culture medium of 1.0 to 10 $\mathrm{mmol} / \mathrm{l}$ when the culture medium $\mathrm{pH}$ is $7 \cdot 6^{40}$; this corresponds to ammonia concentrations of 48 to $480 \mu \mathrm{mol} / \mathrm{l}$, respectively.

Other effects of ammonia are to inhibit endocytosis by cells and the degradation of protein by the lysosome. An extracellular source of

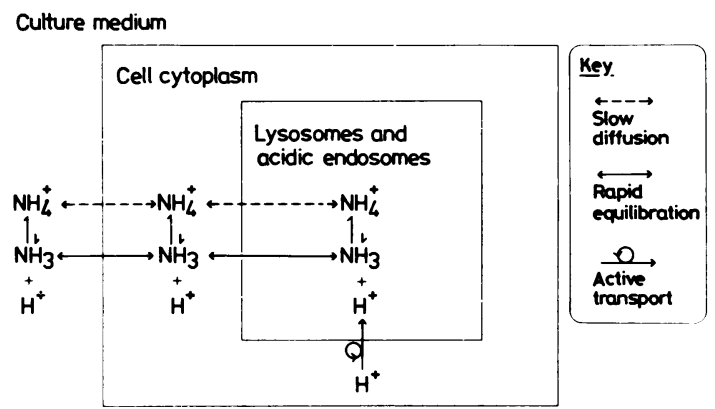

Fig. 1 Ammonia $\left(\mathrm{NH}_{3}\right)$ rapidly diffuses into the lysosomes, and acidic endosomes, where it is converted to ammonium $\left(\mathrm{NH}_{4}{ }^{+}\right)$, which does not readily cross biological membranes. In an attempt to maintain the acidic $\mathrm{pH}$ of the lysosomes, hydrogen ions $\left(\mathrm{H}^{+}\right)$are actively pumped into the lysosomes, thus causing the accumulation of ammonium in the lysosomes. This results in osmotic swelling and eventually vacuolation of the lysosomes. Because of the large volume of culture medium relative to the volume of cells in tissue culture systems, the accumulation of ammonium in the lysosomes has an unmeasurable effect on the concentration of ammonium in the medium, and provided the $\mathrm{pH}$ remains constant the concentration of ammonia will be unchanged. At a steady state the lysosomal $p H$ will depend on the balance resulting from the rapid diffusion of ammonia and the active transport of hydrogen ions into the lysosomes and the slow leakage of ammonium ions out of the lysosomes. 
ammonia is not required as intracellular ammonia production will inhibit lysosomal protein degradation in cells if it is allowed to accumulate. ${ }^{41}$ Endocytosis and lysosomal protein degradation are virtually completely inhibited at a concentration of ammonium in the medium of $10 \mathrm{mmol} / \mathrm{l}$ when the $\mathrm{pH}$ is $7 \cdot 6$, and there is about $75 \%$ and $30 \%$ inhibition with concentrations of 6.0 and $2.0 \mathrm{mmol} / \mathrm{l}$ respectively. ${ }^{4243}$ The explanation for these observations is the effect of ammonia on lysosomal pH (see Fig. 1). Using fluorescein labelled dextran the stable $\mathrm{pH}$ of lysosomes has been found to be $4.75 \pm 0.06$ in cultured cells. The addition of ammonium to the culture medium, with a $\mathrm{pH}$ of 7.6 and at a concentration of $10.0 \mathrm{mmol} / \mathrm{l}$, results in an ammonia concentration in the medium of $480 \mu \mathrm{mol} / \mathrm{l}$ and causes the lysosomal $\mathrm{pH}$ to rise within one minute to over $6 \cdot 3$; it will stabilise at about $6 \cdot 1$ after $4-5 \mathrm{~min}$. If the concentration of ammonium in the culture medium is $1.0 \mathrm{mmol} / \mathrm{l}$, this will result in an ammonia concentration of $48 \mu \mathrm{mol} / \mathrm{l}$, and the $\mathrm{pH}$ will rise to over 5.7 and plateau at $5 \cdot 5 .{ }^{4445}$ This phenomenon is reversible within $5 \mathrm{~min}$. The increase in the intralysosomal $\mathrm{pH}$ will cause inhibition of the lysosomal acid hydrolases, thus decreasing lysosomal protein degradation. This disruption of lysosomal function coupled with the failure to acidify the endosomes adequately will disrupt endocytosis.

Ammonia and other lysosomotropic amines decrease the number of receptors for many ligands on the surfaces of cells. ${ }^{46}$ Peptide hormones, and some other ligands, interact with specific receptors on the surfaces of the cells of their target tissues. These receptor-ligand complexes are endocytosed and, in the acidic environment of the endosome and lysosome, the receptor-ligand complexes dissociate, allowing the receptors to be recycled to the surface of the cell for further usage, while the ligand is degraded in the lysosome. Lysosomotropic amines, by increasing the $\mathrm{pH}$ of the lysosomes and acidic endosomes, prevent receptor-ligand dissociation and lead to an accumulation of receptor-ligand complexes intracellularly, with a resulting depletion of the number of cell surface receptors. This effect of ammonia on hormone receptors has been shown for insulin and epidermal growth factor. ${ }^{4748}$

Ammonia increases the release of $\mathrm{N}$ acetyl- $\beta$-glucosaminidase (E.C.3.2.1.52) and other lysosomal enzymes from the cell without causing the release of the cytoplasmic enzyme lactate dehydrogenase (E.C.1.1.1.27). ${ }^{49}$ Lysosomal enzyme precursors are synthesised in the Golgi apparatus. They possess a 6-phosphomannose residue which binds to a membrane receptor which transports the precursor enzymes to the lysosomes. In the lysosomes the 6-phosphomannose residue is hydrolysed and the precursor enzymes are proteolytically converted to the mature enzyme. Ammonia inhibits the maturation of lysosomal enzymes; the enzyme precursors, which have catalytic activity, are directed to the cell surface, where they become dissociated from the cell and can be measured as secreted enzymes. ${ }^{5051}$

\section{Ammonia, urinary ammonium, and renal tubular cell function}

It is to be expected from the above that if the concentration of ammonia in the renal tubular cells is high enough it will have the following effects. The cells will be vacuolated. The endocytosis of proteins filtered at the glomerulus will be inhibited, thus causing tubular proteinuria. The number of receptors on the surface of the cells will be decreased, which explains the resistance to arginine vasopressin and parathyroid hormone. The release of catalytically active lysosomal enzyme precursors from the renal tubular cells will result in an increase in urinary $\mathrm{N}$-acetyl- $\beta$-glucosaminidase activity. These are some of the major characteristic effects of potassium depletion on the renal tubule. I am not aware of any reports that ammonia or ammonium alters the uptake of amino acids or glucose by cells. However, aminoaciduria and glycosuria do not appear to be features of the renal tubular effects of potassium depletion.

In potassium depleted human subjects or animals? the concentration of ammonia has not been directly measured in intrarenal fluids - namely, renal tubular fluid, renal blood, or interstitial fluid; however, the urine $\mathrm{pH}$ and the concentration of urinary ammonium have been measured (such urinary ammonium measurements are invariably the sum of the total urinary ammonium concentration plus the total urinary ammonia concentration). Urinary ammonium is formed from ammonia which is produced in the renal tubular cells and passively diffuses into the tubular fluid. As hydrogen ions secrete into the tubular fluid ammonium ions are formed, which cannot diffuse back into the renal tubular cells and are excreted in the urine. ${ }^{51}$

Because ammonia diffuses rapidly through renal tissue, the urinary ammonium concentration in conjunction with the urinary $\mathrm{pH}$, the $\mathrm{pK}$ of ammonium and applying the law of mass action, can be used to estimate the concentration of ammonia in the renal tubular cells. This has been verified experimentally by isotope dilution measurements in dogs. ${ }^{52}$ Micropuncture studies in rats have shown that the partial pressure of ammonia in the first, second, and final thirds of the proximal renal tubule are the same as in the distal tubule and equal to that of the renal venous blood. Concentration of ammonium, how- 


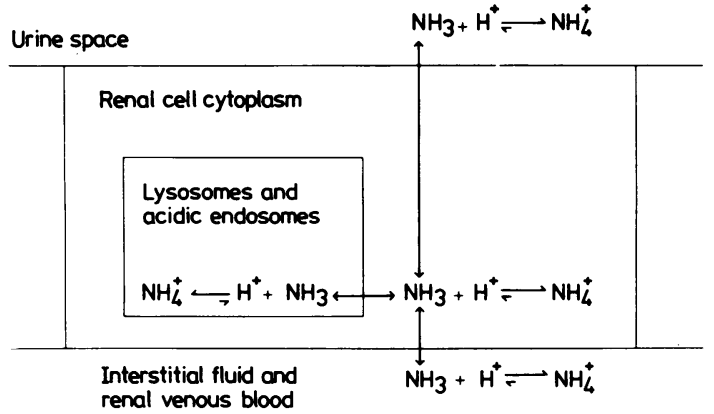

Fig. 2 The partial pressure of ammonia $\left(\mathrm{pNH}_{3}\right)$ in the fuid of the first, second, and funal thirds of the proximal renal tubule is the same as that in the distal tubule and equal to that of the renal venous blood. As the ammonia in urine and renal venous blood originates from the renal tubular cells, it is not unreasonable to deduce that this concentration of ammonia will be equal to, or perhaps even slightly less, than that in the renal tubular cell cytoplasm and lysosomes.

Unlike ammonia the concentration of ammonium increases in the tubular fuid as it proceeds along the nephron, but it does so in accordance with changes in the $p H$ and, as predicted from the $p K$ of ammonium, the concentration of ammonia and the Law of Mass Action. These data indicate that the urine $\mathrm{pH}$ and ammonium concentration may be used to estimate the concentration of ammonia in the renal tubular cells.

ever, increases along the renal tubule but does so in relation to the $\mathrm{pH}$ of the tubular fluid ${ }^{\mathrm{s}}$ (Fig. 2).

Cells exposed to $6.0 \mathrm{mmol} / \mathrm{l}$ ammonium in culture media at $\mathrm{pH} 7.6$ become vacuolated, and endocytosis and lysosomal protein degradation are both inhibited by about $75 \% . .^{394142}$ The same intracellular ammonia concentration in the renal tubular celi would result in a urinary ammonium concentration of $38 \mathrm{mmol} / \mathrm{l}$ when the urine $\mathrm{pH}$ was 6.8 or $60 \mathrm{mmol} / \mathrm{l}$ at $\mathrm{pH} 6.6$. In healthy subjects such high urinary ammonium concentrations associated with these relatively high urinary $\mathrm{pH}$ values are not encountered. In potassium depletion the concentration of ammonia in the renal tubular cells is high enough to result in urinary ammonium concentrations of this magnitude with the urine $\mathrm{pH}$ at such relatively high levels. ${ }^{13}$ I therefore propose that the morphological changes and some of the functional defects in the renal tubule seen in patients with severe potassium depletion are caused by high concentrations of ammonia in the kidney. The high concentrations of ammonia are due to a primary increase in renal ammoniagenesis caused by potassium depletion.

I wish to thank Dr PO Seglen for discussions on lysosomal function and Dr G Walters for his con- structive criticisms of my argument and advice.

\section{References}

' Schrader GA, Prickett CO, Salmon WD. Symptomatology and pathology of potassium and magnesium deficiencies in the rat. J Nutr 1937; 14:85-109.

${ }^{2}$ Relman AS, Schwartz WB. The nephropathy of potassium depletion. N Engl J Med 1956;255: 195-203.

${ }^{3}$ Toback FG, Ordonez NG, Bortz SL, Spago BH. Zonal changes in renal structure and phospholipid metabolism in potassium deficient rats. Lab Invest 1976;34:115-24.

${ }^{4}$ Beck N, Webster SK. Impaired urinary concentrating ability and cyclic AMP in potassium depleted rat kidney. Am J Physiol 1976;231:1204-8.

${ }^{5}$ Beck N, Davis BA. Impaired renal response to parathyroid hormone in potassium depletion. Am J Physiol 1975;228:179-83.

- Buter EA, Flynn FV, Harris H, Robson EB. A study of urine proteins by two dimensional electrophoresis with special reference to the proteinuria of renal tubular disorders. Clin Chim Acta 1962;7:34-41.

${ }^{7}$ Morgan DB. Assessment of renal tubular function and damage and their clinical significance. Ann Clin Biochem 1982;19:307-13.

${ }^{8}$ Stanbury SW, Macauley D. Defects of renal tubular function in the nephrotic syndrome. $Q J$ Med 1957;26:7-30.

${ }^{9}$ Earle DP, Sherry S, Eichna LW, Conal NJ. Low potassium syndrome due to defective renal tubular mechanisms for handling potassium. Am J Med 1951;11:283-301.

${ }^{10}$ Beskind $\mathrm{H}$, Mudge GH. Effect of potassium deficiency on renal tubular reabsorption and assimilation of glucose. Bull Johns Hopkins Hosp 1959; 104:252-9.

" Denton DA, Wynn V, McDonald JR, Simon S. Renal regulation of the extracellular fluid II. Acta Med Scand 1951; suppl 261: 1-202.

${ }^{12}$ Eales L, Linder GC. Primary aldosteronisin. Some observations on a case in a coloured Cape woman. $Q J$ Med 1956;25:539 64.

${ }^{13}$ Schwartz WB, Relaman AS. Metabolic and renal studies in chronic potassium depletion resulting from overuse of laxatives. J Clin Invest 1953;32:258-71.

14 Dustan HP, Corcoran AC, Page IH. Renal function in primary aldosteronism. J Clin Invest 1956;35: 1357-63.

is Black DAK, Milne MD. Experimental potassium depletion in man. Clin Sci 1952;11:397-415.

${ }^{16}$ Huth EJ, Squires RD, Elkinton JR. Experimental potassium depletion in normal subjects: II. Renal and hormonal factors in the development of extracellular alkalosis during depletion. J Clin Invest 1959;38:1149-65.

${ }^{17}$ Tannen RL, Wedell E, Moore R. Renal adaption to high potassium intake: the role of hydrogen ion. J Clin Invest 1973;52:2089-101.

18 Tannen RL, McGill J. The influence of potassium on renal ammonia production. Am J Physiol 1976;231:1178-84.

${ }^{19}$ Tannen RL, Kunin AS. Effects of potassium on ammoniagenesis by renal mitochondria. Am J Physiol 1976;231:44-51.

${ }^{20}$ Tannen RL. Ammonia metabolism. Am J Physiol 1978;235:F265-77.

${ }^{21}$ Adam WR, Simpson DP. Renal mitochondrial glutamine metabolism and dietary potassium and protein content. Kidney Int 1975; 7:325-30.

${ }^{22}$ Goldstein L. Relation of renal glutamine transaminase-waminidase activity to ammonia excretion in the rat. Nature 1964;201:1229-30.

${ }^{23}$ Bogusky RT, Lowenstein LM, Lowenstein JM. The purine nucleotide cycle; a pathway for ammonia production in the rat kidney. J Clin Invest 1976;58:326-35.

${ }^{24} \mathrm{Kamm}$ DE, Strope GL. Glutamine and glutamate metabolism in 
renal cortex from potassium-depleted rats. Am J Physiol 1973; 224: 1241-8.

2s Sleeper RS, Belanger P, Lemieux G, Preuss HG. Effects of in vitro potassium on ammoniagenesis in rat and canine kidney tissue. Kidney Int 1982;21:345-53.

${ }^{26}$ Sastrasinh S, Tannen RL. Mechanism by which enhanced ammonia production reduces urinary potassium excretion. Kidney Int 1981;20:326-31.

${ }^{27}$ Tannen RL. The effect of uncomplicated potassium depletion on urine acidification. $J$ Clin Invest 1970;49:813-27.

${ }^{2 *}$ Van Ypersele de Strihou C, Dieu JP. Potassium deficiency acidosis in the dog. Kidney Int 1977;11:335-47.

${ }^{24}$ Conway EJ. Apparatus for the micro determination of certain volatile substances. IV. The blood ammonia, with observations on normal human blood. Biochem J 1935;29:2755-72.

${ }^{30}$ Conway EJ, Cooke W. Blood ammonia. Biochem J 1939;33:457-87.

" Forman DT. Rapid determination of plasma ammonia by an ion exchange technic. Clin Chem 1964;10:497-508.

${ }^{32}$ Gips $\mathrm{CH}$, Wibbens-Alberts M. Ammonia determination in blood using the TCA direct method. Clin Chim Acta 1968;22:183-6.

"3 Ishihara A, Kurahasi K, Neharu H. Enzymatic determination of ammonia in blood plasma. Clin Chim Acta 1972;41:225-61.

${ }^{34}$ Tada K, Okuda K, Watanabe K, Iimnra Y. A new method for screening for hyperammonemia. Eur $J$ Pediatr 1979; 130: 105-10.

${ }^{35}$ Kleiner D. The transport of $\mathrm{NH}_{3}$ and $\mathrm{NH}_{4}+$ across biological membranes. Biochem Biophys Acta 1981;639:41-52.

${ }^{36}$ Bates RG, Pinching GD. Dissociation constant of aqueous ammonia at $0^{\circ}$ to $50^{\circ}$ from Emf studies of the ammonium salt of a weak acid. J Am Chem Soc 1950;72:1393-6.

${ }^{37}$ Heinz R. Morphologishe Veranderungen der Rothen Blutkorperchen dur gifte. Virchows Arch 1980; 122:112-6.

${ }^{3 *}$ Seglen PO, Reith A. Ammonia inhibition of protein degradation in isolated rat hepatocytes. Exp Cell Res 1976; 100:276-80.

${ }^{34}$ DeDuve C, DeBarsy T, Poole B, Truet A, Tulkens P, Van Hoof F. Lysosomotropic agents. Biochem Pharmacol 1974;23: 2495-534.

${ }^{40}$ Ohkuma S, Poole B. Cytoplasmic vacuolation of mouse peritoneal macrophages and the uptake into lysosomes of weakly basic substances. J Cell Biol 1981;90:656-64.

${ }^{4}$ Seglen PO. Protein degradation in isolated rat hepatocytes is inhibited by ammonia. Biochem Biophys Res Comm 1975;66:44-52.

${ }^{42}$ Livesly G, Williams KE, Knowles SE, Ballard FJ. Effects of weak bases on the degradation of endogenous and exogenous proteins by rat yolk sacs. Biochem J 1980;188:895-903.

${ }^{43}$ Seglen PO, Grinde B, Solheim AE. Inhibition of the lysosomal pathway of protein degradation in isolated hepatocytes by ammonia, methylamine, chloroquine and leupeptin. Eur $J$ Biochem 1979;95:215-25.

${ }^{44}$ Ohkuma S, Poole B. Lysosomotropic amines and lysosomal $\mathrm{pH}$. Proc Natl Acad Sci USA 1978;75:3327-31.

${ }^{45}$ Poole B, Ohkuma S. Effect of weak bases on the intralysosomal $\mathrm{pH}$ in mouse peritoneal macrophages. J Cell Biol 1981;90:665-9.

${ }^{46}$ Seglen PO. Inhibitors of lysosomal function. Methods in Enzymology 1983;96J:737-64.

${ }^{47}$ Marshall S, Green A, Olefsky JM. Evidence for recycling of insulin receptors in isolated rat adipocytes. $J$ Biol Chem 1981;256: 11464-70.

${ }^{48}$ McKanna JA, Haigler HT, Cohen S. Hormone receptor topology and dynamics: morphological analysis using ferritin-labelled epidermal growth factor. Proc Natl Acad Sci USA 1979; 76:5689-93.

${ }^{44}$ Riches DWH, Stanworth DR. Primary amines induce selective release of lysosomal enzymes from mouse macrophages. Biochem J 1980; 188:933-6.

${ }^{\text {so }}$ Hasilik A, Neufeld EF. Biosynthesis of lysosomal enzymes on fibroblasts: Synthesis as precursors of high molecular weight. $J$ Biol Chem 1980;255:4937-45.

s! Hasilik A, Neufeld EF. Biosynthesis of lysosomal enzymes in fibroblasts: phosphorylation of mannose. J Biol Chem 1980;255:4946-4950.

52 Pitts RF. Production and excretion of ammonia in relation to acid-base regulation. In: Orloff J, Berliner RW, eds. Handbook of physiology. Renal physiology. Washington DC: American Physiology Society, 1973:455-96.

${ }^{53}$ Stone WJ, Balagura S, Pitts RF. Diffusion equilibrium for ammonia in the kidney of the acidotic dog. J Clin Invest 1967; 46: 1603-8.

${ }^{54}$ Oelert H, Uhlich E, Hills AG. Messungen des ammoniakdruckes in den corticalen tubuli der rattenniere. Arch Ges Physiol 1968;300:35-48.

Requests for reprints to: Dr DStJ O' Reilly, Department of Pathological Biochemistry, Royal Infirmary, Glasgow, G4 OSF, Scotland. 